\title{
Louis Braille (1809-1852): A criação de um código de leitura para cegos e o seu emprego no ensino de química atual
}

\author{
Sandra Franco-Patrocínio (UFJF) \\ Jomara Mendes Fernandes (UFJF) \\ Ivoni Freitas-Reis (UFJF)
}

\section{RESUMO-COMUNICAÇÃO ORAL}

Louis Braille (1809-1852) ainda na adolescência ingressou no Instituto Real dos Jovens Cegos em Paris - criada em 1784, tendo sido a primeira escola destinada às pessoas com cegueira. Nesse centro de estudos, ensinava-se a ler através da impressão forte de textos em papel, que permitia dar relevo às letras. Buscando desenvolver um método que facilitasse a leitura dos cegos, Braille criou um código, que levou o seu nome - o código Braille, utilizado até os dias atuais. No Brasil, em 1854, o Imperador D. Pedro II (1825-1891) fundou a primeira instituição voltada a alunos cegos, o Imperial Instituto de Meninos Cegos, denominado atualmente de Instituto Benjamin Constant, que seguiu os mesmos preceitos do Instituto francês. Posteriormente, foram criadas outras instituições em diferentes estados brasileiros. Para que a aprendizagem dos conceitos químicos não ficasse limitada às pessoas que enxergam, surgiu a necessidade de buscar dentro do código Braille formas de caracterizar o conhecimento químico. Nesse sentido, o Ministério da Educação criou o manual Grafia Química Braille para uso no Brasil (2002). Portanto, temos como objetivo nesse trabalho, mostrar o percurso trilhado para a consolidação do código Braille desde sua criação até a atualidade no Brasil, principalmente no ensino de química. 